\title{
Geochemistry and Mineralogy of the Upper Cretaceous-Paleocene Marine Series, Iullemmeden Basin, Niger Republic
}

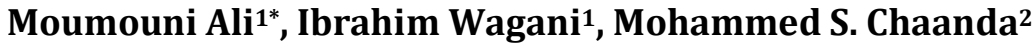 \\ ${ }^{1}$ Département de Géologie, Faculté des Sciences et Techniques, Université Dan Dicko Dankoulodo, Maradi, Niger Republic \\ ${ }^{2}$ School of Geography, Earth \& Environmental Sciences, University of Plymouth, Drake Circus, UK \\ Email: *alimoumouni2005@yahoofr
}

How to cite this paper: Ali, M., Wagani, I., \& Chaanda, M. S. (2019). Geochemistry and Mineralogy of the Upper Cretaceous-Paleocene Marine Series, Iullemmeden Basin, Niger Republic. Journal of Geoscience and Environment Protection, 7, 1-19. https://doi.org/10.4236/gep.2019.712001

Received: October 8, 2019

Accepted: December 9, 2019

Published: December 12, 2019

Copyright $\odot 2019$ by author(s) and Scientific Research Publishing Inc. This work is licensed under the Creative Commons Attribution International License (CC BY 4.0).

http://creativecommons.org/licenses/by/4.0/

\begin{abstract}
Major and trace elements, mineralogy as well as the total organic content of the Upper Cretaceous-Paleocene Marine Series of the Iullemmeden basin in Niger were determined in order to assess their composition, the chemistry of the paleoenvironment and the nature of the parent crystalline rocks that they evolved from. The major and trace elements were analyzed using a Bruker Tracer IV energy-dispersive hand held X-ray fluorescence spectrometer, the mineralogical analyses were done using a Bruker AXS D8 Discover, while the total organic carbon was calculated by subtraction of inorganic carbon from the total carbon, determined using a CM5014 coulometer (UIC, Joliet, IL, USA) and a LECO SC-144DR instrument. Geochemical indices calculated from major oxides such as CIA, PIA, ICV and CIW have been computed and the results show that the Marine Series are made essentially of clay minerals of the smectite group (montmorillonite), quartz and other accessory minerals like rutile and calcite. Computed ratios of some trace elements such as $\mathrm{V} /(\mathrm{V}+$ $\mathrm{Ni}$ ) and $\mathrm{V} /(\mathrm{V}+\mathrm{Cr}$ ) showed that the paleoenvironment was dysoxic-oxic and the low values $(<2)$ of the Total Organic Carbon found in the sediments are justified by those poor preservative conditions. Based on $\mathrm{Al}_{2} \mathrm{O}_{3} / \mathrm{TiO}_{2}$ ratios, the sediments were derived from intermediate to acidic igneous rocks surrounding the basin.
\end{abstract}

\section{Keywords}

Geochemistry and Mineralogy

\section{Introduction}

The Marine Series constitutes one of the three major lithostratigraphic groups of 
the Iullemmeden Basin which is a large intracontinental depression overlying a buried rift system. It is bordered to the north by the igneous masses of Adrar des Iforas, the Hoggar and Air Mountains; to the south by the Eburnean Basement; to the east by the Air-Damagaram Mounio axis and communicating to the west with the Taoudeni Basin (Figure 1). The marine Series is stratigraphically found between the Continental Intercalaire group at the base and the Continental Terminal group at the top. Formed during a series of Upper Cretaceous-Lower Tertiary marine transgressions, it is characterized by an alternating sequence of claystones/shales and limestones globally attributed to climatic oscillations rather than sea level fluctuations: long periods of deposition of shales with secondary gypsum formed as a result of sulfide evolution, separated by relatively brief episodes of oxygenation (Mathey et al., 1991). Previous studies on the series include those of Boeckh (1965), Greigert (1966, 1979), Greigert \& Pougnet (1967), Brodbeck et al. (1987), Dikouma et al. (1987), Dikouma (1990), Mathey et al. (1991), Kogbe (1981), Meister et al. (1992), and Alzouma (1994). Most of these works placed emphasis on the biostratigraphy and facies description of the formations.

Less has been published on the geochemistry and mineralogy of the rocks, specifically in the Dakoro region, where the basal part of the Marine Series occupies a Cenomanian-Turonian cuesta. In this region, a toxic gas has been reported (Greigert, 1979) to emanate from the Marine Series, resulting to the death of some people in the course of digging water wells. Brodbeck et al. (1987)

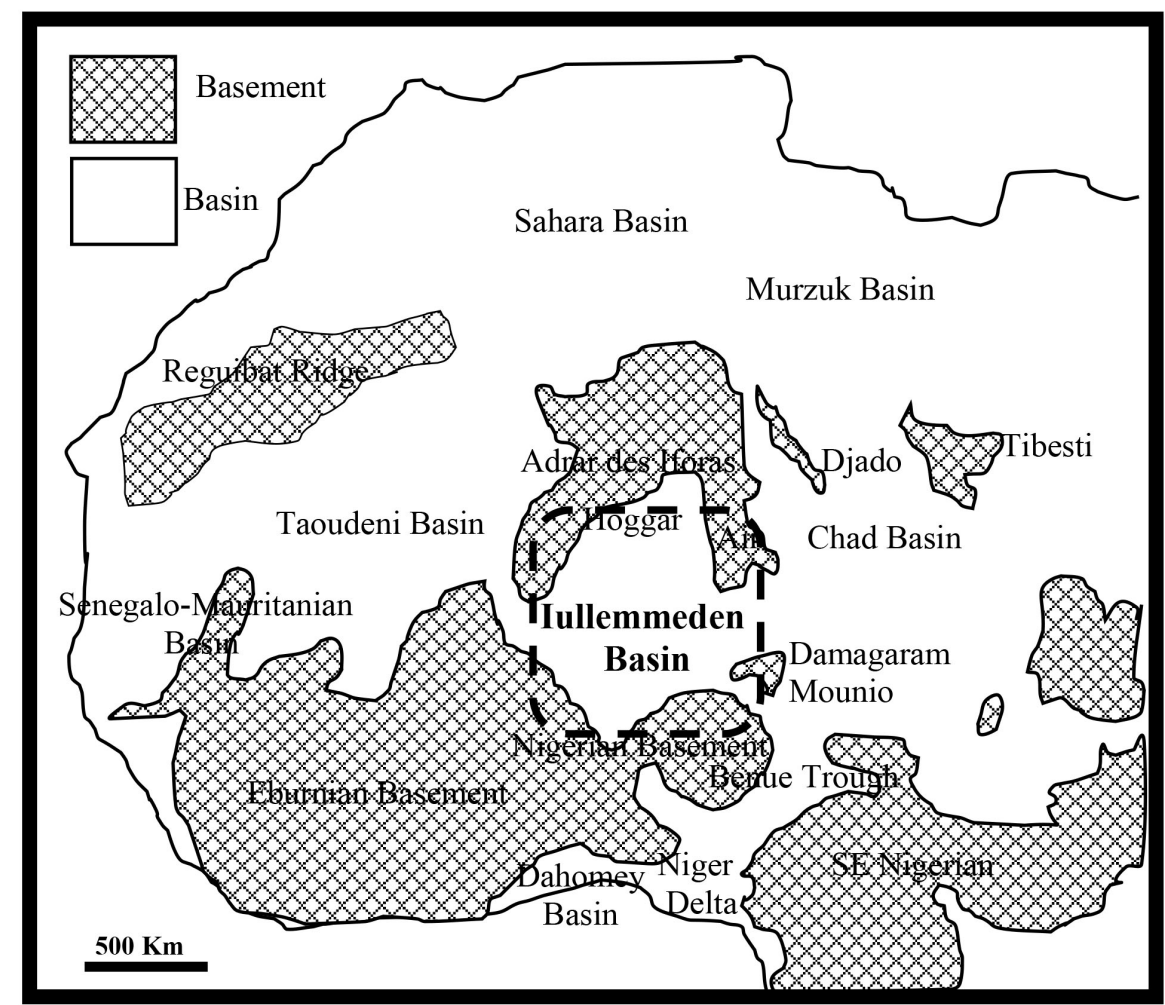

Figure 1. Location map of the iullemmeden basin (Modified from Alzouma (1994)). 
advanced the notion that the gas could be hydrogen sulfide $\left(\mathrm{H}_{2} \mathrm{~S}\right)$ as a result of bacterial sulfate reduction, methane $\left(\mathrm{CH}_{4}\right)$ from anaerobic decomposition of organic matter, or carbon dioxide $\left(\mathrm{CO}_{2}\right)$ from aerobic oxidation of organic matter and pyrite. Moumouni \& Fryar (2017) investigated on groundwater from some dug wells and boreholes and sediments of the Marine Series. They found out the presence of high acetate concentrations, low $\mathrm{SO}_{4}-\mathrm{S}$ relative to total $\mathrm{S}$, and/or a rotten-egg odor, all of which are consistent with reduction of $\mathrm{SO}_{4}^{2-}$ to $\mathrm{H}_{2} \mathrm{~S}$.

This study aims at assessing the composition, depositional paleoenvironment of the Marine Series and deduces the parent rock types that they originated from. This is carried out through determination of major and trace elements, mineralogy. The total organic carbon (TOC) is also determined in order to link the preservation of the organic matter with the chemistry of the sediments. Many factors influence sediment composition, including source rock composition, chemical weathering, climate, transport, burial, and diagenesis. Pettijohn (1975) and Graver \& Scott (1995) stated that shales retain most of the mineral constituents of the source and their bulk chemistry preserves the near-original signature of the provenance much better than any other siliciclastic rock. Provenance, depositional palaeoenvironments, and paleoweathering conditions of siliciclastic rocks have been studied using geochemical ratios and indices such as $\mathrm{Al}_{2} \mathrm{O}_{3} / \mathrm{SiO}_{2}, \mathrm{Al}_{2} \mathrm{O}_{3} / \mathrm{TiO}_{2}, \mathrm{~K}_{2} \mathrm{O} / \mathrm{Al}_{2} \mathrm{O}_{3}, \mathrm{~K}_{2} \mathrm{O} / \mathrm{Na}_{2} \mathrm{O}, \mathrm{TOC} / \mathrm{S}$, CIA (chemical index of alteration), PIA (plagioclase index of alteration), ICV (index of compositional variability), and CIW (chemical index of weathering). Examples include Dickinson \& Suczek (1979), Bhatia (1983), Bhatia \& Crook (1986), Roser \& Korsch (1986), McLennan \& Taylor (1991), Cox et al. (1995). Suttner \& Dutta (1986) successfully used $\mathrm{SiO}_{2}$ versus $\left(\mathrm{Al}_{2} \mathrm{O}_{3}+\mathrm{K}_{2} \mathrm{O}+\mathrm{Na}_{2} \mathrm{O}\right)$ to assess the paleoclimatic conditions of fluvial sandstones in the Cutler Formation (Permian) and Fountain Formation (Permian-Pennsylvanian) in Colorado and in the Gondwana Supergroup (Permian-Triassic) of Peninsular India.

\section{Geologic History and Setting}

During the Upper Cenomanian-Mid Turonian/Senonian, the first Cretaceous marine transgressions invaded the area from the north and the calcareous sandstones, fine sandstones, and gypsiferous, glauconitic, and fossiliferous shales of the Marine Series were deposited. These deposits show rapid facies changes and typify a detrital continental-platform style of sedimentation, following a general transgression interrupted by a brief regressive episode (Kogbe, 1981). Each individual transgression overlapped the preceding one in a south-westerly direction (Figure 2). The detritic fraction (here sandstones) might have occurred from the alteration of the underlying continental deposits. As described by Brodbeck et al. (1987), the lower part of the Marine Series in the Dakoro area consists of $\sim 10 \mathrm{~m}$ of thick gray to dark silty shales locally rich in pyrite, or gypsum and crowned with decameter-thick beds of calcareous shells (lumachelles).

Greigert (1966) defined six marine transgressions: three in the Cretaceous and the other three in the latest Cretaceous and earliest Tertiary. Greigert \& Pougnet (1967) 


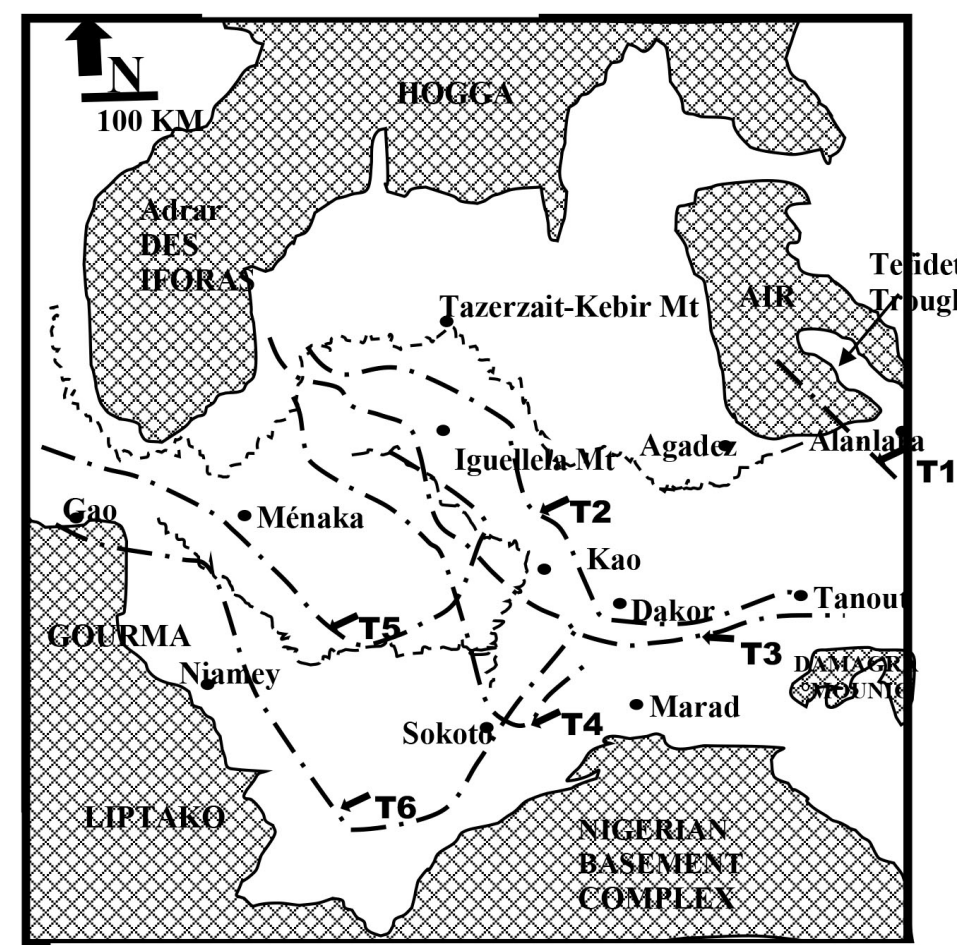

Figure 2. Cretaceous-Tertiary transgressions (T1-T6) in the Iullemmeden basin, modified from Greigert (1966) and Alzouma (1994).

distinguished two marine transgressions of Late Cenomanian and Early Turonian, respectively, by the presence of Neolobites vibrayeanus and Nigericeras.

However, Meister et al. $(1991,1992)$ found these same two species in the Late Cenomanian in nearly the whole Iullemmeden Basin, and thus concluded that a single transgression occurred during the Late Cenomanian and Early Turonian. Hence, five marine transgressions are now considered for the Marine Series, which are detailed in the following sections.

\subsection{Mont Iguella Formation, the White Limestone and the Overlying Unit}

The Late Cenomanian-Early Turonian transgression of Meister et al. $(1991,1992)$ deposited the Mont Iguella Formation in the Iullemmeden basin. It is a calcareous and siliciclastic succession that consists of thinly bedded, gray to yellow, fine to medium, often carbonaceous sandstones, intercalated with gypsiferous gray shales and yellow marly limestones (Alzouma, 1994). Its base corresponds to the fluviatile sandstones of the Continental Intercalaire. The associated fossils include lamellibranches, gastropods, echinoids and ammonites. The second, Late Turonian-Coniacian transgression of Meister et al. $(1991,1992)$ is marked by Coilopoceras inflatum and shaly limestone that Greigert (1966) named as the White Limestone Formation. In the area west of Abalak, this is marked by a prominent topographic feature, where mottled purple-green siltstones are capped by a marly gray limestone, which in turn is overlain by a massive, chert veined, white, recrystallized limestone (Moody and Sutcliffe, 1991). Above the White 
Limestone is a marly limestone (Overlying Unit) that is relatively rich in fossils (dinosaur and crocodile bones, fish teeth, etc.).

\subsection{Majia Group}

The third and fourth marine transgressions occurred during the CampanianLower Maastrichtian and Upper Maastrichtian, respectively, and were marked by Libycoceras. The Maastrichtian period was marked by the deposition of the Majia Group in western Niger; its lateral equivalent in the Sokoto area of Nigeria is called the Rima Group. The Majia Group consists of the Alambanya, Farin Doutchi, and Inwagar formations. These are respectively named the Taloka, Dukamaje, and Wurno formations in the Sokoto sector. The Taloka is also called the Lower Sandstones and Mudstones, the Farin Doutchi is called the Mosasaurus Shale, and the Inwagar is called the Upper Sandstones and Mudstones. In the Dakoro area, the Marine Series is overlain by the Taloka Formation, which consists of white fine-grained friable sandstones and siltstones with thin intercalated mudstones and carbonaceous shales. Thick Quaternary aeolian sands overlie these units, making outcrops very scarce, and the subsurface geology is unveiled only by borehole data.

During Upper Paleocene, the fifth marine transgression deposited the Garadoua Formation, which is equivalent to the Sokoto Group in Nigeria. The members of the Garadoua Formation are the Kao, the Tamaske and the Barmou from base to top. These correspond to the Dange, Kambaina and Gamba units, respectively, in the Sokoto Group. The base of the Garadoua Formation is observed in Garadoua village (Figure 3) and is made of slightly indurated bluishgray shale, interbedded with thin layers of yellowish-brown limestone as the Dange Unit. Greigert (1966) called the base and the top of the Garadoua Formation "Schiste papyracé" (papyraceous shale) because of the very fissile nature of the two horizons. This formation has been mined for cement both in Niger and Nigeria for decades for the quality of the limestone it contains and the clay and gypsum potential of the underlying Farin Doutchi or Dukanmaje Formation. The fauna are very diverse and include bivalves, echinoids (Linthia soudanensis), gastropods, nautilus and foraminifera (Ranikauthalia). The Marine Series is well exposed in the Tahoua area of Niger as seen below (Figure 3).

The general geological map of the Iullemmeden basin established by Greigert (1966) and modified by successive researchers is presented below (Figure 4).

\section{Materials and Methods}

A total of 32 ditch cutting samples of shale facies from boreholes were collected from three different localities namely Kaya, Dandadji and Tahoua. The area covered represents the central part of the depocenter of the Marine Series of the Iullemmeden basin in Niger. These include 13, 10 and 9 samples from Kaya, Dandadji and Tahoua boreholes respectively (Figure 4 and Figure 5). 


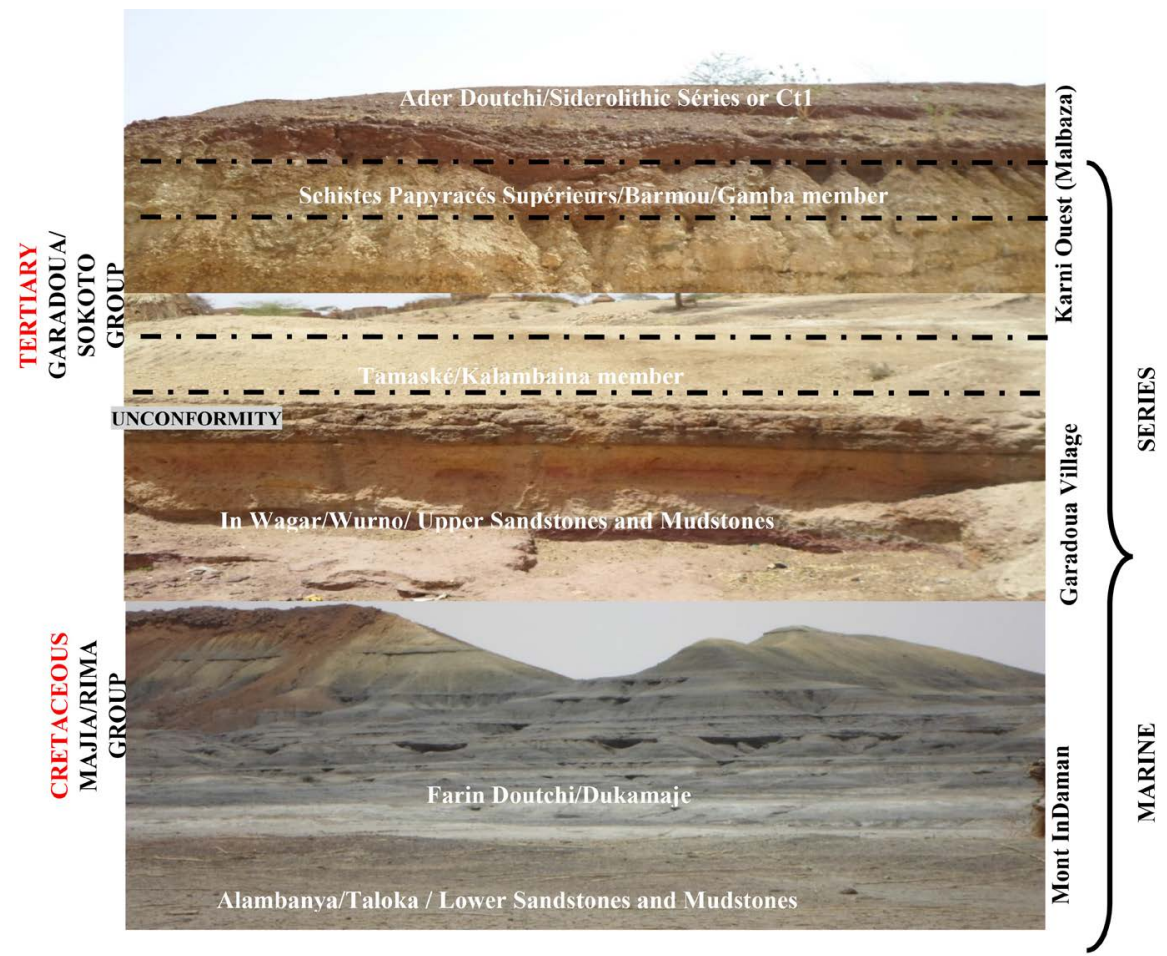

Figure 3. Outcrops of the marine series in tahoua area of niger.

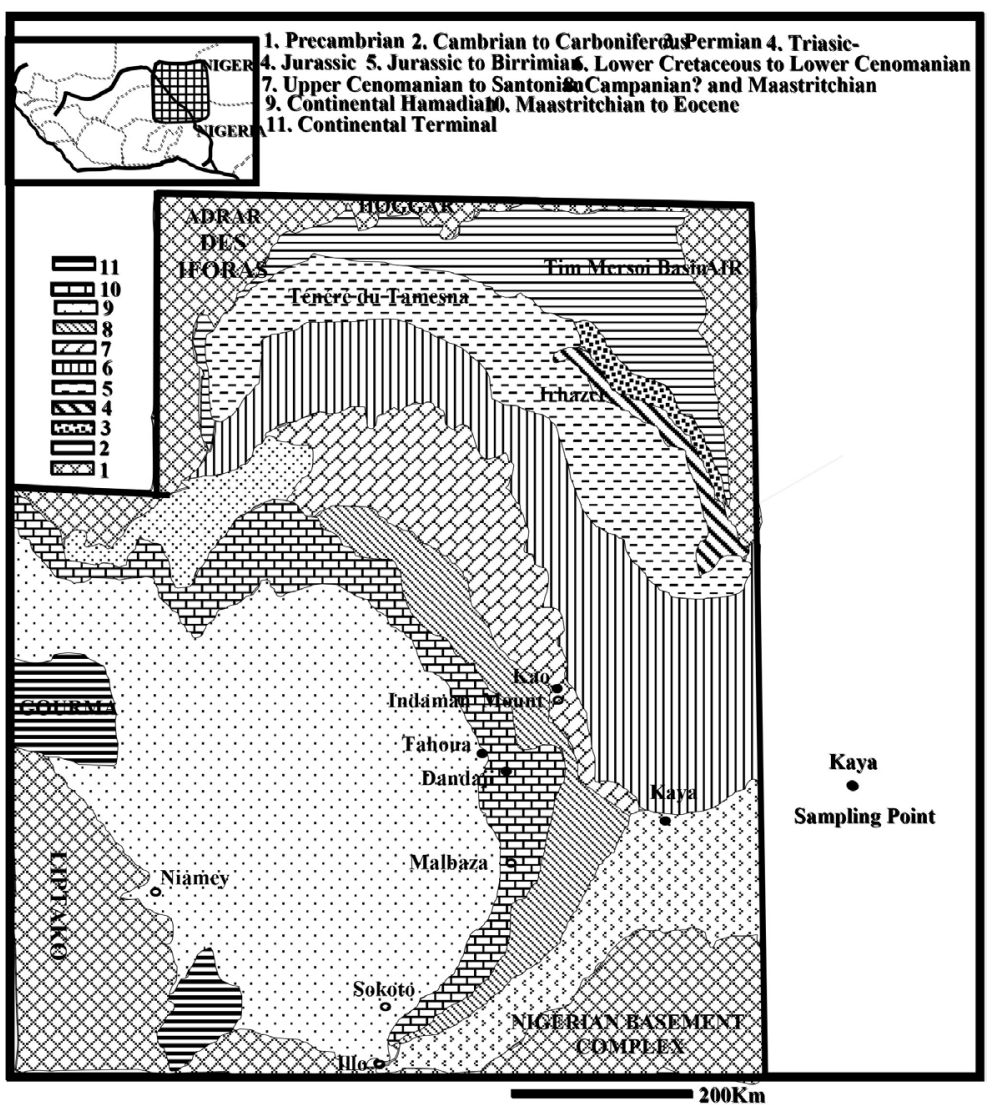

Figure 4. General geological map of the Iullemmeden basin, modified from Bellion (1987). 
TAHOUA (TA)

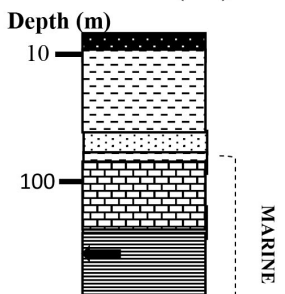

$\sum_{\substack{\frac{\pi}{2} \\ x}}^{3}$

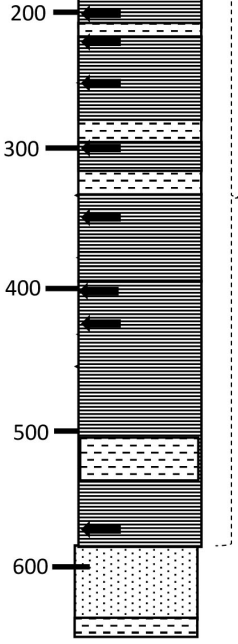

DANDAJI (DJ)

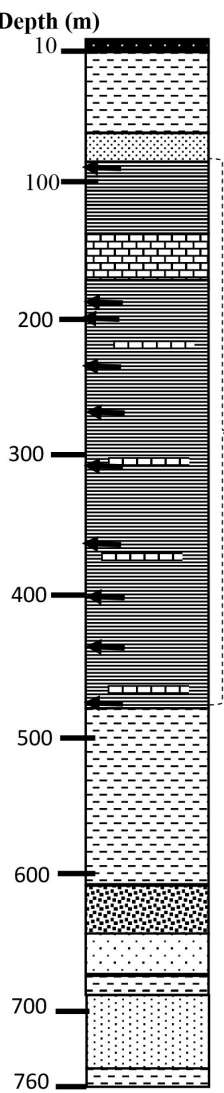

$\operatorname{KAYA}(\mathbf{K})$

Depth (m)

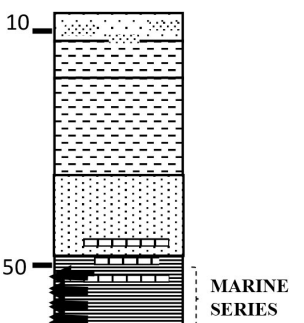

100

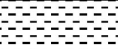
IES

50

+
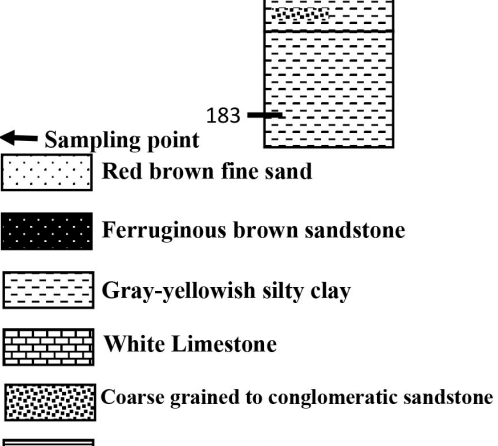

Figure 5. Litho-logs and sampling points.

All the analyses were carried out at the University of Kentucky, Kentucky State, USA. All the samples had been ground in an agate mortar and sieved to $0.125 \mathrm{~mm}$ size. Major and trace elements were analyzed using a Bruker Tracer IV energy-dispersive hand held $\mathrm{x}$-ray fluorescence spectrometer at the Pioneer Laboratory of the Department of Earth and Environmental Sciences. The XRF gun is fitted with a $40 \mathrm{keV}$ and $60 \mu \mathrm{A} \mathrm{X}$-ray tube. Chemical data were collected over 90 seconds in order to maximize the signal-to-noise ratio. Marked sample points were analyzed twice, once each for major and trace element chemistry, respectively. Major elements with atomic number $11-26$, were collected at 15 $\mathrm{keV}$ and $35 \mu \mathrm{A}$ under vacuum conditions of 9 torr. Trace elements, with atomic 
number 20 - 51, were collected at $40 \mathrm{keV}$ and $15 \mu \mathrm{A}$, without a vacuum. The rock chosen as a reference material was SARM-41, a shale standard from South Africa (Ring, 1993). SARM-41 was run at the beginning and end of each three foot core box, in order to determine stability and reproducibility of the ED-XRF. Raw counts collected by the gun were calibrated and converted to elemental weight percentages using Bruker proprietary software and the empirical calibrations of Rowe et al. (2012). The calibrations of Rowe et al. (2012) were determined by comparing results of various analytical measurements (e.g., ICP-MS and WD-XRF) to the compositions of a suite of 90 mudrocks. Accuracy of the measurements decreases for lighter elements, such as sodium and magnesium.

Samples were analyzed for total inorganic carbon using a CM5014 coulometer (UIC, Joliet, IL, USA) and for total carbon and sulfur using the LECO SC-144DR instrument at the Kentucky Geological Survey (KGS). Total organic carbon was calculated by subtraction of inorganic carbon from the total carbon. For the mineralogical analyses, 11 of the samples ( 4 from Kaya, 4 from Dandadji and 3 from Tahoua) were analyzed using a Bruker AXS D8 Discover at the KGS.

\section{Results and Discussion}

\subsection{Composition, Maturity and Palaeoweathering of the Marine Series}

Cox et al. (1995) and Moosavirad et al. (2011) stated that the major element composition of fine siliciclastic rocks is usually controlled by clay minerals and non-clay silicate phases. Table 1 displays the values of major oxides of the Marine Series (mostly the shaly horizons). Silica is the most abundant constituent in all the samples with values range between 19.1 and $44.58 \mathrm{wt} \%$. The next oxide in abundance is alumina $\left(\mathrm{Al}_{2} \mathrm{O}_{3}\right)$ ranging between 8.17 and 4.15 wt \% followed by $\mathrm{Fe}_{2} \mathrm{O}_{3}\left(3.27\right.$ - 18.23 wt \%), $\mathrm{CaO}\left(1.10-11.20\right.$ wt \%), $\mathrm{SO}_{3}\left(0.68-4.37\right.$ wt \%), $\mathrm{Na}_{2} \mathrm{O}$ (0.66 - 1.37 wt \%), $\mathrm{TiO}_{2}\left(0.50-1.40\right.$ wt \%), $\mathrm{K}_{2} \mathrm{O}(0.05-1.51$ wt \%), $\mathrm{MgO}(0.17-$ 0.62 wt \%), $\mathrm{P}_{2} \mathrm{O}_{5}\left(0.06-0.44\right.$ wt \%), $\mathrm{MnO}\left(0.05-0.29\right.$ wt \%) and $\mathrm{Cr}_{2} \mathrm{O}_{3}(0.00-$ 0.01 wt \%).

In order to assess the composition, maturity and weathering of the sediments, geochemical indices such as the CIA, PIA, ICV and CIW have been computed as described by Nesbitt \& Young (1982), Roser \& Korsch (1988), Cox et al. (1995), Cullers (2000), and Hofmann et al. (2001):

$$
\begin{aligned}
& \mathrm{CIA}=100 \times\left[\mathrm{Al}_{2} \mathrm{O}_{3} /\left(\mathrm{Al}_{2} \mathrm{O}_{3}+\mathrm{CaO}^{*}+\mathrm{Na}_{2} \mathrm{O}+\mathrm{K}_{2} \mathrm{O}\right)\right] \\
& \mathrm{PIA}=100 \times\left[\left(\mathrm{Al}_{2} \mathrm{O}_{3}-\mathrm{K}_{2} \mathrm{O}\right) /\left(\mathrm{Al}_{2} \mathrm{O}_{3}+\mathrm{CaO}^{*}+\mathrm{Na}_{2} \mathrm{O}-\mathrm{K}_{2} \mathrm{O}\right)\right] \\
& \mathrm{ICV}=\left(\mathrm{Fe}_{2} \mathrm{O}_{3}+\mathrm{K}_{2} \mathrm{O}+\mathrm{Na}_{2} \mathrm{O}+\mathrm{CaO}+\mathrm{MgO}+\mathrm{MnO}\right) / \mathrm{Al}_{2} \mathrm{O}_{3} \\
& \mathrm{CIW}=100 \times\left[\mathrm{Al}_{2} \mathrm{O}_{3} /\left(\mathrm{Al}_{2} \mathrm{O}_{3}+\mathrm{CaO}^{*}+\mathrm{Na}_{2} \mathrm{O}\right)\right]
\end{aligned}
$$

The values of CIA, PIA and CIW range between 23.02 - 75.1; 23.02 - 75.43 and 25.43 - 76.57 respectively (Table 2). Nesbitt \& Young (1982) stated that CIA values are 0 for diopside; 30 to 45 for fresh basalts; 45 to 55 for granites and granodiorites; 50 for unaltered albite, anorthite and potassic feldspars; 75 for 
Table 1. Major oxides of the Marine Series.

\begin{tabular}{|c|c|c|c|c|c|c|c|c|c|c|c|c|}
\hline ID & $\mathrm{Al}_{2} \mathrm{O}_{3}$ & $\mathrm{CaO}$ & $\mathrm{Cr}_{2} \mathrm{O}_{3}$ & $\mathrm{Fe}_{2} \mathrm{O}_{3}$ & $\mathrm{~K}_{2} \mathrm{O}$ & $\mathrm{MgO}$ & $\mathrm{MnO}$ & $\mathrm{Na}_{2} \mathrm{O}$ & $\mathrm{P}_{2} \mathrm{O}_{5}$ & $\mathrm{SO}_{3}$ & $\mathrm{SiO}_{2}$ & $\mathrm{TiO}_{2}$ \\
\hline K53 & 7.85 & 5.33 & 0.00 & 6.02 & 1.03 & 0.24 & 0.27 & 1.16 & 0.15 & 1.02 & 26.25 & 0.70 \\
\hline K54 & 7.59 & 2.86 & 0.01 & 5.08 & 1.27 & 0.39 & 0.10 & 1.33 & 0.09 & 1.27 & 29.88 & 0.64 \\
\hline K55 & 6.55 & 4.83 & 0.00 & 5.42 & 1.51 & 0.31 & 0.17 & 1.16 & 0.14 & 1.90 & 29.06 & 0.50 \\
\hline K56 & 6.80 & 4.11 & 0.00 & 5.59 & 1.33 & 0.31 & 0.15 & 1.16 & 0.14 & 1.77 & 27.94 & 0.59 \\
\hline K57 & 7.97 & 5.25 & 0.00 & 6.65 & 0.93 & 0.29 & 0.29 & 1.12 & 0.12 & 0.88 & 25.42 & 0.74 \\
\hline K58 & 6.89 & 2.47 & 0.01 & 5.55 & 1.30 & 0.44 & 0.08 & 1.24 & 0.12 & 1.80 & 29.17 & 0.61 \\
\hline K59 & 7.82 & 2.62 & 0.01 & 5.14 & 1.20 & 0.38 & 0.10 & 1.31 & 0.11 & 1.37 & 30.26 & 0.65 \\
\hline K60 & 7.36 & 6.52 & 0.00 & 5.53 & 0.95 & 0.22 & 0.28 & 1.14 & 0.14 & 1.22 & 25.84 & 0.65 \\
\hline K61 & 7.91 & 1.95 & 0.01 & 5.46 & 1.20 & 0.34 & 0.09 & 1.29 & 0.09 & 1.17 & 30.46 & 0.73 \\
\hline K62 & 7.58 & 1.75 & 0.01 & 4.95 & 1.20 & 0.48 & 0.07 & 1.36 & 0.10 & 0.98 & 31.21 & 0.68 \\
\hline K63 & 7.63 & 1.71 & 0.01 & 4.95 & 1.22 & 0.50 & 0.07 & 1.37 & 0.08 & 0.91 & 31.61 & 0.73 \\
\hline K64 & 8.17 & 1.16 & 0.01 & 4.88 & 1.30 & 0.51 & 0.06 & 1.34 & 0.07 & 0.84 & 31.77 & 0.79 \\
\hline K65 & 7.15 & 1.10 & 0.01 & 4.46 & 1.33 & 0.62 & 0.05 & 1.47 & 0.06 & 0.68 & 30.58 & 0.70 \\
\hline DJ93 & 5.76 & 1.20 & 0.002 & 18.23 & 0.05 & 0.17 & 0.22 & 0.66 & 0.35 & 1.34 & 19.10 & 0.87 \\
\hline DJ192 & 4.15 & 11.20 & 0.005 & 4.85 & 0.51 & 0.19 & 0.07 & 0.97 & 0.32 & 1.83 & 22.76 & 0.91 \\
\hline DJ200 & 4.84 & 9.90 & 0.000 & 3.74 & 0.57 & 0.22 & 0.11 & 1.08 & 0.44 & 1.34 & 25.74 & 1.13 \\
\hline DJ234 & 6.11 & 2.59 & 0.008 & 3.88 & 0.51 & 0.37 & 0.08 & 1.21 & 0.16 & 1.96 & 37.07 & 0.98 \\
\hline DJ276 & 5.00 & 2.07 & 0.008 & 4.28 & 0.39 & 0.38 & 0.07 & 1.19 & 0.17 & 2.46 & 38.89 & 0.99 \\
\hline DJ320 & 4.26 & 1.47 & 0.009 & 2.92 & 0.13 & 0.52 & 0.06 & 1.32 & 0.15 & 1.66 & 44.58 & 0.82 \\
\hline DJ370 & 5.53 & 2.14 & 0.008 & 3.76 & 0.40 & 0.44 & 0.06 & 1.20 & 0.16 & 1.54 & 38.77 & 1.06 \\
\hline DJ400 & 5.29 & 2.30 & 0.006 & 4.22 & 0.34 & 0.43 & 0.08 & 1.24 & 0.14 & 1.32 & 37.25 & 1.09 \\
\hline DJ445 & 5.17 & 1.39 & 0.007 & 3.27 & 0.36 & 0.49 & 0.08 & 1.27 & 0.14 & 1.56 & 41.83 & 1.01 \\
\hline DJ479 & 6.19 & 1.23 & 0.011 & 5.09 & 0.22 & 0.47 & 0.05 & 1.31 & 0.13 & 1.64 & 36.21 & 0.81 \\
\hline TA150 & 4.65 & 6.60 & 0.000 & 3.46 & 0.55 & 0.22 & 0.10 & 1.14 & 0.34 & 1.69 & 28.31 & 1.24 \\
\hline TA200 & 5.17 & 7.73 & 0.004 & 5.80 & 0.56 & 0.20 & 0.09 & 0.99 & 0.20 & 1.09 & 26.36 & 1.10 \\
\hline TA220 & 6.87 & 2.37 & 0.002 & 4.06 & 0.87 & 0.32 & 0.11 & 1.28 & 0.14 & 1.37 & 32.89 & 1.31 \\
\hline TA250 & 5.62 & 2.61 & 0.001 & 5.44 & 0.81 & 0.24 & 0.16 & 1.10 & 0.35 & 1.48 & 33.79 & 1.11 \\
\hline TA300 & 5.84 & 3.83 & 0.001 & 3.88 & 0.71 & 0.25 & 0.11 & 1.09 & 0.21 & 1.19 & 32.56 & 1.40 \\
\hline TA350 & 5.12 & 4.11 & -0.004 & 6.77 & 0.67 & 0.21 & 0.26 & 0.91 & 0.36 & 4.37 & 30.08 & 1.03 \\
\hline TA400 & 6.49 & 2.28 & 0.008 & 5.53 & 0.60 & 0.33 & 0.07 & 1.17 & 0.13 & 1.14 & 32.26 & 1.06 \\
\hline TA422 & 6.18 & 2.70 & 0.008 & 6.06 & 0.47 & 0.28 & 0.08 & 1.16 & 0.17 & 1.30 & 32.05 & 0.95 \\
\hline TA582 & 6.20 & 3.83 & 0.008 & 5.39 & 0.52 & 0.30 & 0.09 & 1.23 & 0.12 & 0.77 & 31.28 & 0.74 \\
\hline
\end{tabular}

muscovite; 75 to 85 for illite, montmorillonite and beidellite; and close to 100 for kaolinite and chlorite. The CIA values found in most of the samples are below 75 , the value of montmorillonite, which was identified as the major clay mineral in mineralogical analyses (Table 3). These CIA values could be underestimated as XRF has a very hard time measuring elements of low energy electrons like Na. hence, the XRD results could be more reliable here. 
M. Ali et al.

Table 2. Calculated geochemical ratios and indices of the Marine Series.

\begin{tabular}{|c|c|c|c|c|c|c|c|c|}
\hline ID & $\mathrm{SiO}_{2} / \mathrm{Al}_{2} \mathrm{O}_{3}$ & $\mathrm{Al}_{2} \mathrm{O}_{3} / \mathrm{TiO}_{2}$ & $\mathrm{~K}_{2} \mathrm{O} / \mathrm{Al}_{2} \mathrm{O}_{3}$ & $\mathrm{~K}_{2} \mathrm{O} / \mathrm{Na}_{2} \mathrm{O}$ & CIA & PIA & ICV & CIW \\
\hline K53 & 3.33 & 11.21 & 0.13 & 0.89 & 51.07 & 51.24 & 1.88 & 54.74 \\
\hline K54 & 4.00 & 11.86 & 0.17 & 0.95 & 58.16 & 60.13 & 1.54 & 64.43 \\
\hline K55 & 4.35 & 13.10 & 0.23 & 1.30 & 46.62 & 45.69 & 2.12 & 52.23 \\
\hline K56 & 4.17 & 11.53 & 0.20 & 1.15 & 50.75 & 50.93 & 1.95 & 56.34 \\
\hline K57 & 3.23 & 10.77 & 0.12 & 0.83 & 52.19 & 52.50 & 1.92 & 55.58 \\
\hline K58 & 4.17 & 11.30 & 0.19 & 1.05 & 57.90 & 60.11 & 1.70 & 65.00 \\
\hline K59 & 3.85 & 12.03 & 0.15 & 0.92 & 60.39 & 62.75 & 1.46 & 66.55 \\
\hline $\mathrm{K} 60$ & 3.57 & 11.32 & 0.13 & 0.83 & 46.09 & 45.56 & 2.08 & 49.00 \\
\hline K61 & 3.85 & 10.84 & 0.15 & 0.93 & 64.05 & 67.44 & 1.40 & 70.94 \\
\hline K62 & 4.17 & 11.15 & 0.16 & 0.88 & 63.75 & 67.23 & 1.38 & 70.91 \\
\hline K63 & 4.17 & 10.45 & 0.16 & 0.89 & 63.96 & 67.54 & 1.38 & 71.24 \\
\hline K64 & 3.85 & 10.34 & 0.16 & 0.97 & 68.25 & 73.32 & 1.23 & 76.57 \\
\hline K65 & 4.35 & 10.21 & 0.19 & 0.90 & 64.71 & 69.37 & 1.36 & 73.56 \\
\hline DJ93 & 3.33 & 6.62 & 0.01 & 0.08 & 75.1 & 75.43 & 3.72 & 75.59 \\
\hline DJ192 & 5.56 & 4.56 & 0.12 & 0.53 & 23.02 & 23.02 & 4.51 & 25.43 \\
\hline DJ200 & 5.26 & 4.28 & 0.12 & 0.53 & 29.53 & 28.00 & 3.46 & 30.59 \\
\hline DJ234 & 6.25 & 6.23 & 0.08 & 0.42 & 58.64 & 59.57 & 1.57 & 61.65 \\
\hline DJ276 & 7.69 & 5.05 & 0.08 & 0.33 & 57.8 & 58.58 & 1.87 & 60.53 \\
\hline DJ320 & 10.00 & 5.2 & 0.03 & 0.1 & 59.33 & 59.68 & 1.70 & 60.43 \\
\hline DJ370 & 7.14 & 5.22 & 0.07 & 0.33 & 59.65 & 60.57 & 1.64 & 62.34 \\
\hline DJ400 & 7.14 & 4.85 & 0.06 & 0.27 & 57.69 & 58.30 & 1.83 & 59.91 \\
\hline DJ445 & 8.33 & 5.12 & 0.07 & 0.28 & 63.13 & 64.39 & 1.52 & 66.03 \\
\hline DJ479 & 5.88 & 7.64 & 0.04 & 0.17 & 69.16 & 70.15 & 1.48 & 70.90 \\
\hline TA150 & 6.25 & 3.75 & 0.12 & 0.48 & 35.94 & 34.63 & 2.86 & 37.53 \\
\hline TA200 & 5.00 & 4.7 & 0.11 & 0.57 & 35.78 & 34.58 & 3.19 & 37.22 \\
\hline TA220 & 4.76 & 5.24 & 0.13 & 0.68 & 60.32 & 62.18 & 1.50 & 65.30 \\
\hline TA250 & 5.88 & 5.06 & 0.14 & 0.74 & 55.42 & 56.46 & 2.04 & 60.24 \\
\hline TA300 & 5.56 & 4.17 & 0.12 & 0.65 & 50.92 & 51.04 & 1.93 & 54.28 \\
\hline TA350 & 5.88 & 4.97 & 0.13 & 0.74 & 47.36 & 46.99 & 2.73 & 50.49 \\
\hline TA400 & 5.00 & 6.12 & 0.09 & 0.51 & 61.57 & 63.06 & 1.70 & 65.29 \\
\hline TA422 & 5.26 & 6.51 & 0.08 & 0.41 & 58.8 & 59.67 & 1.89 & 61.55 \\
\hline TA582 & 5.00 & 8.38 & 0.08 & 0.42 & 52.63 & 52.89 & 1.95 & 55.06 \\
\hline
\end{tabular}

However, Cox et al. (1995) stated that values of $\mathrm{K}_{2} \mathrm{O} / \mathrm{Al}_{2} \mathrm{O}_{3}$ ratio of clays are less than 0.3 and those of feldspars range from 0.3 to 0.9. The values of $\mathrm{K}_{2} \mathrm{O} / \mathrm{Al}_{2} \mathrm{O}_{3}$ ratio of the Marine Series vary from 0.01 to 0.23 (Table 2) that is less than 0.3. These values also indicate preponderance of clay minerals over K-bearing minerals such as K-feldspars and micas (Cox et al., 1995).

In terms of maturity, CIA values plotted against those of ICV show that most of the samples are immature and have been subjected to weak weathering (Figure 6). 
Table 3. Mineralogical composition of some selected samples of the Marine Series.

\begin{tabular}{cccccc}
\hline Sample ID & \multicolumn{2}{c}{ Clay Minerals } & \multicolumn{3}{c}{ Non-Clay Minerals } \\
\hline K54 & Montmorillonite & Kaolinite & Quartz & Rutile & Calcite \\
K60 & Major & Minor & major & Trace & trace \\
K61 & Major & Minor & major & - & trace \\
K63 & Major & Minor & major & - & trace \\
DJ93 & Major & Minor & major & Trace & - \\
DJ200 & Major & Minor & major & - & - \\
DJ320 & Major & Minor & major & - & trace \\
DJ479 & - & - & major & Trace & trace \\
TA200 & - & - & major & - & - \\
TA300 & Major & Minor & major & - & trace \\
TA582 & Major & - & major & - & trace \\
\hline
\end{tabular}

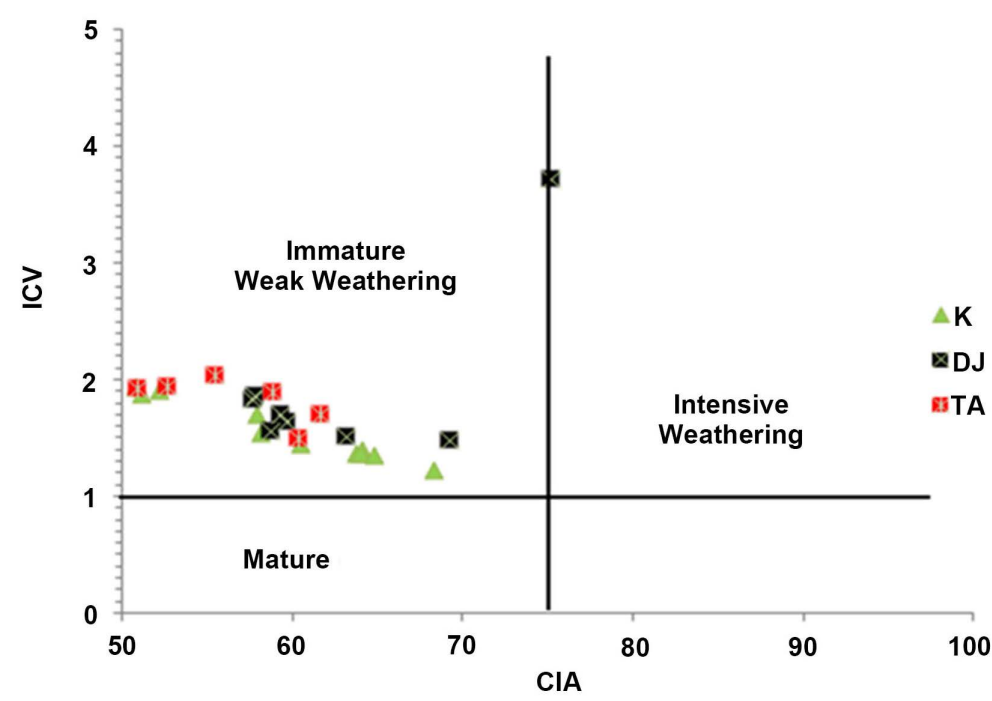

Figure 6. Plot of CIA versus ICV.

This could be also applied to mudrocks as a measure of compositional maturity because minerals show a relationship between resistance to weathering and ICV. Compositionally immature mudrocks that contain a high proportion of non-clay silicate minerals or that are rich in clay minerals such as montmorillonite and sericite will have high values of this index $(>1)$. On the other hand, compositionally mature mudrocks that are poor in nonclay silicates or dominated by minerals such as those of the kandite family (kaolinite, halloysite and dickite) will have low values. Table 2 indicates that the values of ICV of the Marine Series range between 1.13 and 4.2 (>>1), consistent with compositional immaturity. 


\subsection{Paleoenvironment and Tectonic Setting}

A binary diagram of $\mathrm{SiO}_{2}$ versus $\left(\mathrm{Al}_{2} \mathrm{O}_{3}+\mathrm{K}_{2} \mathrm{O}+\mathrm{Na}_{2} \mathrm{O}\right)$ shows that the Marine Series was deposited under wet/humid conditions (Figure 7). This is consistent with the findings of Pascal et al. (1991) and agrees with the hypothesis of generally high rainfall during the Cenomanian-Turonian (Parrish \& Curtis, 1982), in accord with proximity to the equator (Rat et al., 1991).

Trace element ratios have been used as indicators of paleo-redox conditions, including V/Ni by Breit \& Wanty (1991), Wanty \& Goldhaber (1992), Peters \& Moldowan (1993), Galarraga et al. (2008) and Cu/Zn by Hallberg (1976).

Similarly, Zhou \& Jiang (2009) and Pi et al. (2014) stated that V is more effectively fixed in sediments containing organic matter in anoxic environments compared to $\mathrm{Ni}$ and $\mathrm{Cr}$. Therefore, variations in the $\mathrm{V} /(\mathrm{V}+\mathrm{Ni})$ and $\mathrm{V} /(\mathrm{V}+\mathrm{Cr})$ ratios can be used to indicate oxygenation of the depositional environment, and higher $\mathrm{V} /(\mathrm{V}+\mathrm{Ni})$ and $\mathrm{V} /(\mathrm{V}+\mathrm{Cr})$ ratios indicate more strongly reducing conditions. According to Galarraga et al. (2008), a V/Ni ratio higher than 3 indicates that the organic matter was deposited under reducing conditions, while V/Ni ratios ranging between 1.9 and 3 indicate deposition under dysoxic to oxic conditions (mixed terrigenous and marine organic matter) and a V/Ni ratio $<1.9$ indicates predominantly terrigenous organic matter.

From the analytical results of the Marine Series (Table 4), all the V/Ni values are less than 1.9 except for samples $\mathrm{K} 61(\mathrm{~V} / \mathrm{Ni}=2.12)$ and $\mathrm{DJ} 9(\mathrm{~V} / \mathrm{Ni}=10.56)$. All the values of $\mathrm{Cu} / \mathrm{Zn}$ have their ratio lower than 1.9. The ratios $\mathrm{V} /(\mathrm{V}+\mathrm{Ni})$ and $\mathrm{V} /(\mathrm{V}+\mathrm{Cr})$ are either negative or positively low. All the above indicates dysoxic-oxic depositional environment. Rather, all the values of TOC (Table 4) are less than $2 \%$ except in sample DJ234 with value of $2.34 \mathrm{w} \%$. So this explains that the preservation of the organic matter is consistent with the chemistry of rock.

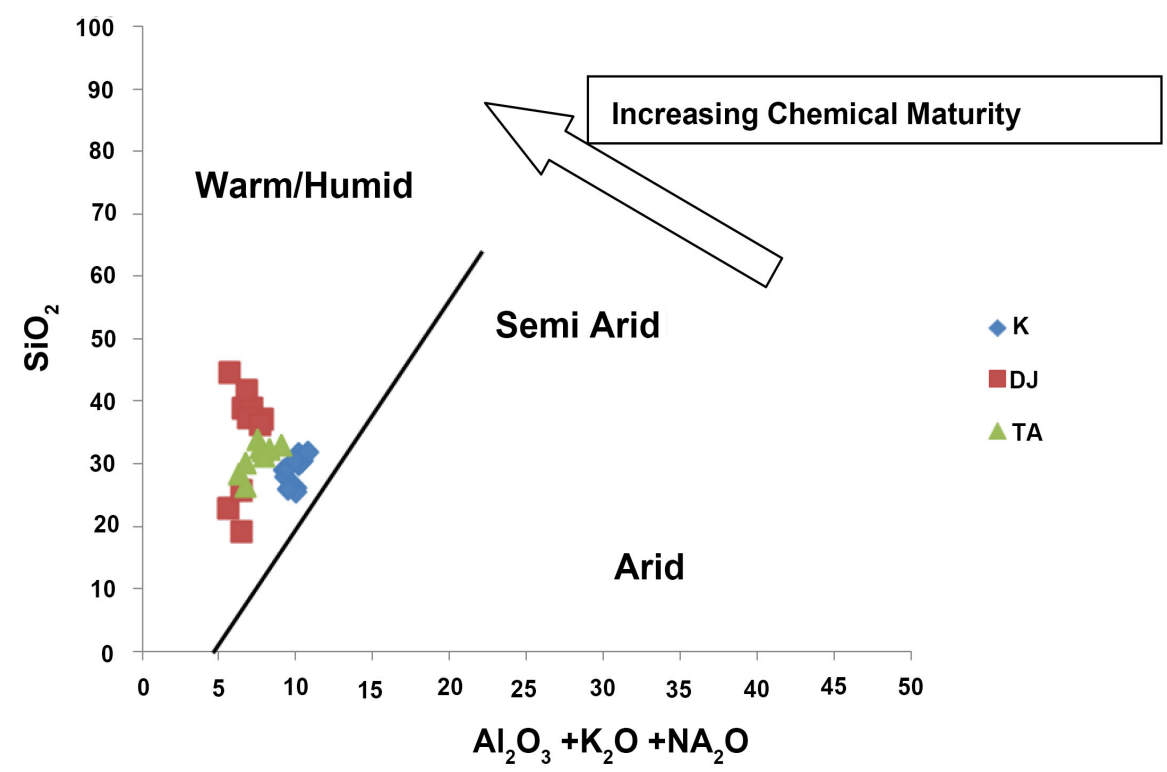

Figure 7. $\mathrm{SiO}_{2}$ versus $\left(\mathrm{Al}_{2} \mathrm{O}_{3}+\mathrm{K}_{2} \mathrm{O}+\mathrm{Na}_{2} \mathrm{O}\right)$ (adapted from Suttner \& Dutta, 1986). 
M. Ali et al.

Table 4. Some trace elements of the marine series.

\begin{tabular}{|c|c|c|c|c|c|c|c|c|c|c|c|c|c|c|}
\hline Sample & Co & $\mathrm{Ni}$ & $\mathrm{Cu}$ & $\mathrm{Zn}$ & $\mathrm{Nb}$ & Mo & $\mathrm{Pb}$ & $\mathrm{V}$ & $\mathrm{Cr}$ & $\mathrm{V} / \mathrm{Ni}$ & $\mathrm{V} /(\mathrm{V}+\mathrm{Ni})$ & $\mathrm{V} /(\mathrm{V}+\mathrm{Cr})$ & $\mathrm{Cu} / \mathrm{Zn}$ & TOC \\
\hline K53 & 0.002414 & 0.002957 & 0.001172 & 0.006457 & 0.000813 & 0.002059 & 0.001269 & 0.00029 & -0.00864 & 0.10 & 0.09 & -0.03 & 0.46 & 0.31 \\
\hline K55 & 0.001667 & 0.002006 & 0.000226 & 0.003359 & 0.00083 & 0.001899 & 0.001232 & 0.00109 & -0.00679 & 0.54 & 0.35 & -0.19 & 0.60 & 1.88 \\
\hline K56 & 0.001912 & 0.00228 & 0.000976 & 0.003551 & 0.000786 & 0.002194 & 0.001106 & 0.00013 & -0.00477 & 0.06 & 0.05 & -0.03 & 0.64 & 1.37 \\
\hline K57 & 0.002422 & 0.002672 & 0.001722 & 0.006743 & 0.000686 & 0.003243 & 0.001278 & 0.001742 & -0.00907 & 0.65 & 0.39 & -0.24 & 0.40 & 0.41 \\
\hline K58 & 0.001844 & 0.002364 & 0.000607 & 0.004067 & 0.000813 & 0.001718 & 0.001168 & 0.000601 & --0.0009 & 0.25 & 0.20 & -2.01 & 0.58 & 1.99 \\
\hline K59 & 0.001579 & 0.002451 & 0.000799 & 0.005065 & 0.000773 & 0.002209 & 0.001271 & 0.001693 & -0.0021 & 0.69 & 0.41 & -4.16 & 0.48 & 0.97 \\
\hline K60 & 0.002041 & 0.002817 & 0.001355 & 0.0051 & 0.000786 & 0.002391 & 0.001167 & -0.00027 & -0.01088 & 0.10 & -0.11 & -0.02 & 0.55 & 0.45 \\
\hline K61 & 0.002014 & 0.002375 & 0.001487 & 0.005495 & 0.000861 & 0.001879 & 0.001252 & 0.005045 & -0.01013 & 2.12 & 0.68 & 0.99 & 0.43 & 0.9 \\
\hline K63 & 0.001571 & 0.002175 & 0.001903 & 0.005572 & 0.000902 & 0.001638 & 0.001211 & -0.00076 & -0.00321 & 0.35 & -0.54 & -0.19 & 0.39 & 0.9 \\
\hline K64 & 0.001648 & 0.002332 & 0.001389 & 0.00548 & 0.000967 & 0.001849 & 0.00146 & 0.000299 & -0.00392 & 0.13 & 0.11 & 0.08 & 0.43 & 0.42 \\
\hline K65 & 0.00143 & 0.002739 & 0.001112 & 0.004455 & 0.000926 & 0.001818 & 0.001461 & -0.00015 & -0.00089 & 0.05 & -0.06 & -0.14 & 0.61 & 0.4 \\
\hline DJ93 & 0.013775 & 0.003551 & 0.003604 & 0.032054 & 0.000735 & -0.00351 & 0.001792 & 0.037496 & 0.07549 & 10.56 & 0.91 & 0.33 & 0.11 & 1.25 \\
\hline DJ192 & 0.002677 & 0.003866 & 0.001111 & 0.007592 & 0.000694 & 0.000264 & 0.001208 & -0.007 & -0.00614 & 1.81 & 2.23 & -0.53 & 0.51 & 0.57 \\
\hline DJ200 & 0.001929 & 0.003497 & 0.000784 & 0.007032 & 0.000828 & -0.00012 & 0.001115 & -0.00643 & -0.01637 & 1.84 & -2.19 & -0.28 & 0.50 & 0.48 \\
\hline DJ234 & 0.002185 & 0.002824 & 0.001565 & 0.005144 & 0.000705 & 0.000701 & 0.001351 & -0.00185 & -0.00809 & 0.66 & -1.90 & -0.19 & 0.55 & 2.43 \\
\hline DJ276 & 0.001812 & 0.002557 & 0.001482 & 0.004902 & 0.000785 & -0.00076 & 0.001134 & -0.00246 & -0.00794 & 0.96 & -25.36 & -0.24 & 0.52 & 1.69 \\
\hline DJ320 & 0.000883 & 0.001985 & 0.000486 & 0.001857 & 0.000661 & -0.00211 & 0.00098 & -0.00347 & -0.01075 & 1.75 & -2.34 & -0.24 & 1.07 & 0.91 \\
\hline DJ370 & 0.001689 & 0.00278 & 0.001083 & 0.005434 & 0.000721 & 0.000993 & 0.001364 & -0.00078 & -0.01119 & 0.28 & -0.39 & -0.07 & 0.51 & 1.82 \\
\hline DJ445 & 0.001333 & 0.002433 & 0.000816 & 0.003737 & 0.000754 & 0.000549 & 0.001041 & -0.00053 & -0.01374 & 0.22 & -0.28 & -0.04 & 0.65 & 1.62 \\
\hline DJ479 & 0.002239 & 0.002789 & 0.002586 & 0.001826 & 0.000592 & 0.000529 & 0.001194 & 0.002301 & -0.00242 & 0.83 & 0.45 & -19.34 & 1.53 & 0.44 \\
\hline TA150 & 0.001584 & 0.003078 & 0.001081 & 0.006867 & 0.000855 & -0.0005 & 0.001135 & -0.00557 & -0.02205 & 1.81 & -2.24 & -0.20 & 0.45 & 0.93 \\
\hline TA200 & 0.002674 & 0.002887 & 0.001025 & 0.008374 & 0.00076 & 0.000403 & 0.001202 & -0.0016 & -0.00962 & 0.55 & -1.24 & -0.14 & 0.34 & 0.64 \\
\hline TA220 & 0.002108 & 0.003732 & 0.001297 & 0.007606 & 0.00081 & 0.000892 & 0.001202 & 0.000636 & -0.01751 & 0.17 & 0.15 & -0.04 & 0.49 & 0.80 \\
\hline TA250 & 0.002609 & 0.002988 & 0.002161 & 0.007415 & 0.000965 & 0.000149 & 0.001358 & 0.001766 & -0.01625 & 0.59 & 0.37 & -0.12 & 0.40 & 0.88 \\
\hline TA300 & 0.001741 & 0.003375 & 0.001205 & 0.006765 & 0.000784 & 0.0011 & 0.001202 & 0.000947 & -0.0192 & 0.28 & 0.22 & -0.05 & 0.50 & 0.87 \\
\hline TA350 & 0.003775 & 0.0062 & 0.001951 & 0.009812 & 0.000883 & $5.99 \mathrm{E}-06$ & 0.001801 & 0.003684 & -0.00986 & 0.59 & 0.37 & -0.60 & 0.63 & 0.83 \\
\hline TA400 & 0.002568 & 0.003576 & 0.002517 & 0.010365 & 0.000822 & 0.000104 & 0.001429 & 0.00407 & -0.00562 & 1.14 & 0.53 & -2.63 & 0.35 & 0.69 \\
\hline TA422 & 0.002867 & 0.004032 & 0.002943 & 0.005867 & 0.000775 & 0.000798 & 0.001444 & 0.002642 & -0.00209 & 0.66 & 0.40 & -4.79 & 0.69 & 0.82 \\
\hline TA582 & 0.001952 & 0.002896 & 0.001384 & 0.002544 & 0.000675 & 0.001538 & 0.001081 & 0.004556 & -0.00336 & 1.57 & 0.61 & -3.81 & 1.14 & 0.65 \\
\hline
\end{tabular}

To determine the provenance of siliciclastic sediments, McLennan et al., (1980) proposed a Ni versus $\mathrm{TiO}_{2}$ discrimination diagram and Floyd et al. (1989) used $\mathrm{Al}_{2} \mathrm{O}_{3}$ versus $\mathrm{TiO}_{2}$ plots. Most of the samples of the Marine Series plot in the acidic field of the $\mathrm{Ni}$ versus $\mathrm{TiO}_{2}$ diagram (Figure 8) and in the alkali granite-granodiorite field of the $\mathrm{Al}_{2} \mathrm{O}_{3}$ versus $\mathrm{TiO}_{2}$ plot (Figure 9), which implies that the sediments originated from acidic igneous rocks. From He et al. (2010) 


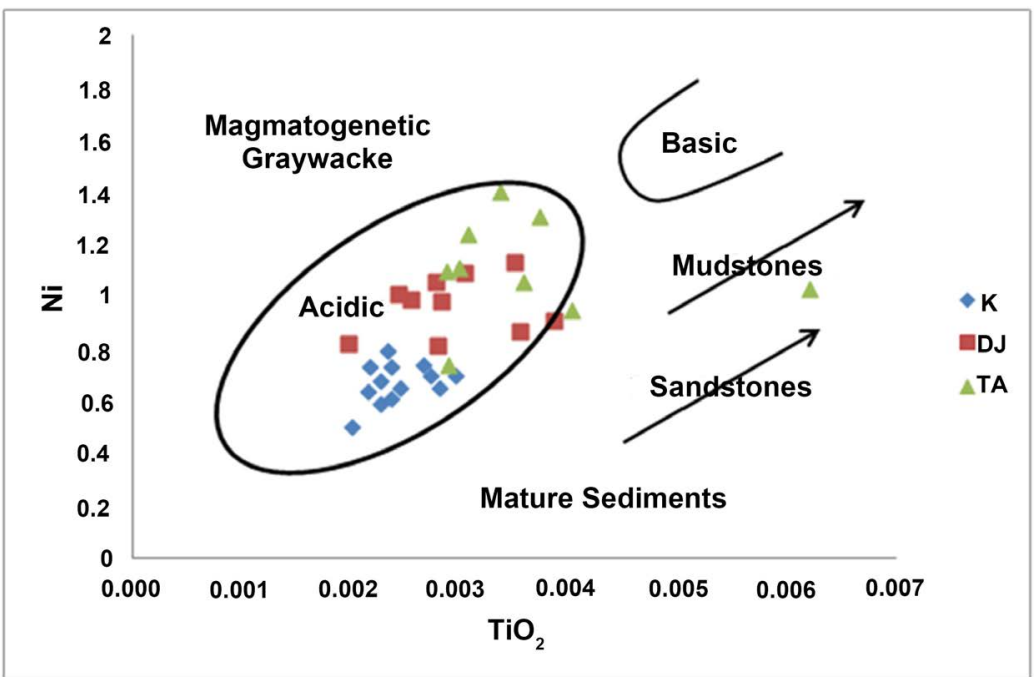

Figure 8. $\mathrm{TiO}_{2}$ versus Ni bivariate diagram (adopted from McLennan et al., 1980).

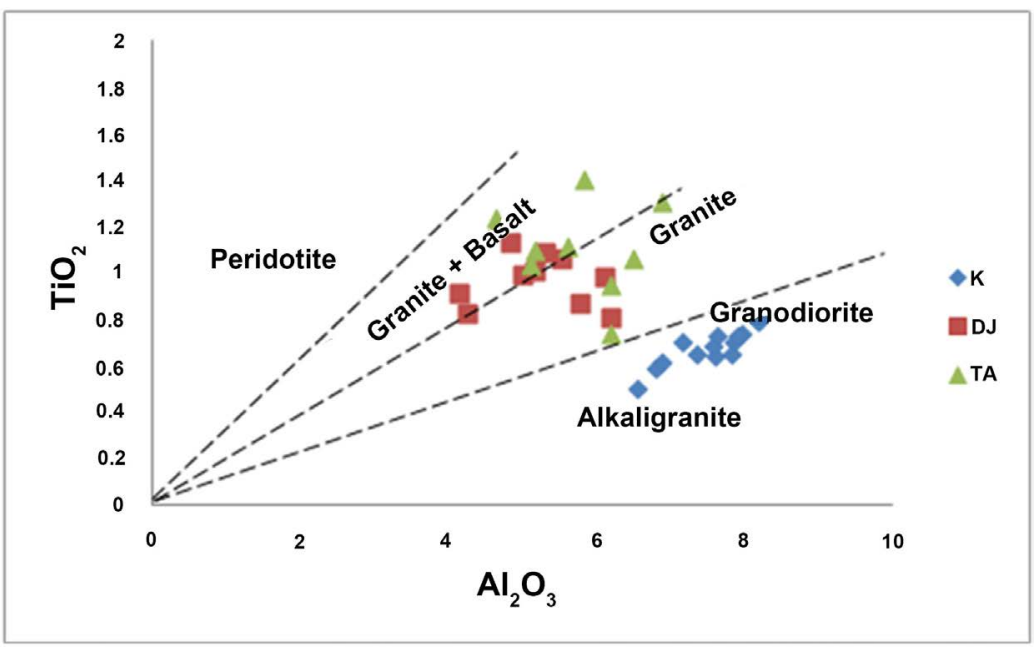

Figure 9. $\mathrm{Al}_{2} \mathrm{O}_{3}$ versus $\mathrm{TiO}_{2}$ bivariate diagram (adopted from Floyd et al., 1989).

and Dai et al. (2015), $\mathrm{Al}_{2} \mathrm{O}_{3} / \mathrm{TiO}_{2}$ ratio and $\mathrm{SiO}_{2}$ contents vary in the igneous rocks as follows: a) $\mathrm{Al}_{2} \mathrm{O}_{3} / \mathrm{TiO}_{2}$ were 3 to 8 in mafic igneous rocks $\left(\mathrm{SiO}_{2}\right.$ content from 45 to 52 wt. \%), b) $\mathrm{Al}_{2} \mathrm{O}_{3} / \mathrm{TiO}_{2}$ ratios were 8 to 21 in intermediate igneous rocks $\left(\mathrm{SiO}_{2}\right.$ content from 53 to 66 wt. \%), and c) $\mathrm{Al}_{2} \mathrm{O}_{3} / \mathrm{TiO}_{2}$ ratios were 21 to 70 in felsic igneous rocks $\left(\mathrm{SiO}_{2}\right.$ content from 66 to $76 \mathrm{wt}$. \%). The $\mathrm{Al}_{2} \mathrm{O}_{3} / \mathrm{TiO}_{2}$ ratios of most the studied sediments range from 4 to 13 implying that the source rocks of these sediments are intermediate igneous rocks.

The source of the sediments can be traced from the contiguous Aïr crystalline basement rocks in the north and the Zinder-Nigeria cristalline basement rocks in the South. Indeed, three periods of volcanism had been identified in previous studies (Yahaya, 1992; Wagani, 2007, etc.) namely Carboniferous, Permian and Jurassic. Karche \& Vachette (1976), Sempéré (1981) and Gerbeaud (2006) mentioned that most of the Paleozoic and Mesozoic sediments in the northern adjacent Tim Mersoï basin derived from the degradation and erosion of the Tuareg 
Shield as at that period of time, the Air was uplifted upstream of the paleocurrents that fed the Iullemmeden basin. The presence of smectite clays such as montmorillonite (main mineral in bentonite) can be supported by the argument made by Fisher \& Schminck (1984) who observed in USA that pyroclastic materials from high volcanic eruptions can be transported and deposited as far as $1000 \mathrm{Km}$. Bentonite is a rock formed of highly colloidal and plastic clays and is produced by in-situ devitrification of volcanic ash. Its presence in the area of study had been earlier mentioned in previous studies by Gourouza et al. (2011; 2013) and in similar Cretaceous lithology (the Pindiga Formation) by Arabi et al. (2017) in the Benue Trough.

\section{Conclusion}

The present work shows that the Marine Series are made predominantly of clay minerals of the smectite group (montmorillonite), quartz and other accessory minerals like rutile and calcite. The sediments are immature and were deposited under dysoxic-oxic conditions which may justify the poor preservation of organic matter in the environment. In terms of origin, the sediments were derived from intermediate to acidic igneous rocks found adjacent to the basin. The occurrence of montmorillonite in the sediments by previous works is also confirmed in this study and the origin may be linked to the volcanic ash that evolved from volcanic eruptions that occurred in late Paleozoic-Mesozoic period in the North and South crystalline basement surrounding the basin. The bentonite potential and its source may be considered as a perspective investigation in the basin with the recent oil discovery success in Niger.

\section{Acknowledgements}

The analytical work was carried out at the University of Kentucky, USA by the first author who beneficiated from the Fulbright Fellowship. The Fulbright Foundation, the Staff of the Earth and Environmental Sciences Department as well as that of the Kentucky Geological Survey are all acknowledged for their respective assistance.

\section{Conflicts of Interest}

The authors declare no conflicts of interest regarding the publication of this paper.

\section{References}

Alzouma, K. (1994). Fluctuations du niveau marin au cours du Mésozoïque et du Cénozoïque dans le bassin intracratonique des Iullemmeden (Niger, Afrique occidentale). Africa Geosciences Review, 1, 131-281.

Arabi, A. S., Dewu, B. B. M., Oladipo, M. O. A., \& Funtua, I. I. (2017). Mineralogy and Rheology of Raw and Activated Turonian to Coniacian Clays from Benue Trough, Northeastern Nigeria. Egyptian Journal of Petroleum, 27, 75-88. https://doi.org/10.1016/j.ejpe.2017.01.004 
Bellion, T. (1987). Histoire géodynamique post-paléozoique de l'afrique de l'ouest d'après l'étude de quelques bassins sédimentaires (sénégal, taoudenni, iullemmeden, tchad).

Bhatia, M. R. (1983). Plate Tectonics and Geochemical Composition of Sandstones. The Journal of Geology, 91, 611-627. https://doi.org/10.1086/628815

Bhatia, M. R., \& Crook, K. A. W. (1986). Trace Element Characteristics of Graywackes and Tectonic Setting Discrimination of Sedimentary Basins. Contributions to Mineralogy and Petrology, 92, 181-193. https://doi.org/10.1007/BF00375292

Boeckh, E. (1965). Contribution à l'étude hydrogéologique de la zone sédentaire de la République 288 du Niger. Ministère des Travaux publics et des Mines de la république du Niger. Technical 289 Report DAK 64-A 20, Dakar, Senegal: BRGM/BFBH.

Breit, G. N., \& Wanty, R. B. (1991). Vanadium Accumulation in Carbonaceous Rocks: A Review of Geochemical Controls during Deposition and Diagenesis. Chemical Geology, 91, 83-97. https://doi.org/10.1016/0009-2541(91)90083-4

Brodbeck, J. F., Burri, M., Ibrahim, I., Pellet, P., \& Schroeter, P. (1987). Region de Dakoro, Etat des 291 Connaissances. Report to Ministère de l'Hydraulique et d'Environnement, Direction des 292 Ressources en Eau, République du Niger.

Cox, R., Lowe, D. R., \& Cullers, R. L. (1995). The Influence of Sediment Recycling and Basement Composition on Evolution of Mudrock Chemistry in the Southwestern United States. Geochimica et Cosmochimica Acta, 59, 2919-2940.

https://doi.org/10.1016/0016-7037(95)00185-9

Cullers, R. L. (2000). The Geochemistry of Shales, Siltstones and Sandstones of Pennsylvanian-Permian Age, Colorado, USA: Implications for Provenance and Metamorphic Studies. Lithos, 51, 181-203. https://doi.org/10.1016/S0024-4937(99)00063-8

Dai, S., Li, T., Jiang, Y., Ward, C. R., Hower, J. C., Sun, J., Liu, J., Song, H., Wei, P., Li, Q., Xie, P., \& Huang, Q. (2015). Mineralogical and Geochemical Compositions of the Pennsylvanian Coal in the HailiushuMine, Daqingshan Coalfield, Inner Mongolia, China: Implications of Sediment-Source Region and Acid Hydrothermal Solutions. International Journal of Coal Geology, 137, 92-110.

https://doi.org/10.1016/j.coal.2014.11.010

Dickinson, W. R., \& Suczek, C. A. (1979). Plate Tectonics and Sandstone Composition. AAPG Bulletin, 63, 2164-2182. https://doi.org/10.1306/2F9188FB-16CE-11D7-8645000102C1865D

Dikouma, M. (1990). Fluctuations du niveau marin au Maastritchien et au Paléocène dans le bassin intracratonic des Iullemmeden (Ader Doutchi-Niger) (272 p.). Thèse de Doctorat, Dijon: University of Burgundy

Dikouma, M., Alzouma, K., Lang, J., Laurin, B., Pascal, A, Trichet, J., Carbonnel, G., \& Tintant, H. (1987). Maastrichien and Paleocene Transgressions and Regression in Western Niger: Shoreline Oscillations (pp. 337). Terra Cognita EUG IV.

Fisher, R. V., \& Schminck, H. U. (1984). Pyroclastic Rocks (472 p.). Berlin, Heidelberg, New York, Tokyo: Spinger-Verlag.

Floyd, P. A., Franke, W., Shail, R., \& Dorr, W. (1989). Geochemistry and Tectonic Setting of Lewisian Clastic Metasediments from the Early Proterozoic Loch Maree Group of Gairloch, NW Scotland. Precambrian Research, 45, 203-214. https://doi.org/10.1016/0301-9268(89)90040-5

Galarraga, F., Reategui, K., Martïnez, A., Martínez, M., Llamas, J. F., \& Márquez, G. (2008). V/Ni Ratio as a Parameter in Palaeoenvironmental Characterisation of NonMature Medium-Crude Oils from Several Latin American Basins. Journal of Petroleum Science and Engineering, 61, 9-14. https://doi.org/10.1016/j.petrol.2007.10.001

Gerbeaud, O. (2006). Evolution structurale du bassin de Tim Mersoï: Le rôle des défor- 
mations de la couverture sédimentaire sur la mise en place des gisements uranifères du secteur d'Arlit (Niger) (260 p). Thèse de Doctorat, Orsay, France: Université de Paris Sud.

Gourouza, M., Natatou, I., \& Boos A. (2011). Physico-Chemical Characterisation of Sabon-Karré's Clay. Journal of Materials and Environmental Science, 2, 415-422.

Gourouza, M., Zanguina, A., Natatou, I., \& Boos, A. (2013). Caracterisation d'une argile mixte du Niger Characterization of a Mixed Clay Niger. Revue CAMES Sciences des Structures et de la Matière, 1, 29.

Graver, J. I., \& Scott, T. J., (1995). Trace Elements in Shale as Indicators of Crustal Provenance and Terrain Accretion of the Southern Canadian Cordillera. Geological Society of America Bulletin, 107, 440-453.

Greigert, J. (1966). Formations crétacé et tertiaires du bassin des iullemmeden (afrique occidentale). In Direction Des Mines Et De La Géologie, République Du Niger (pp. 234). Publication No. 2 Anonymous Editions du Bureau de Recherche Géologiques et Minières.

Greigert, J. (1979). Atlas des Eaux souterraines du Niger, État des Connaissances (Mai 1978), 295 Tome 1, Fasicule I. Généralités sur la Géologie, la Climatologie, l’Hydrologie et les Unités 296 aquifères. Report to Ministère des Mines et de l'Hydraulique, République du Niger. Orléans, France: Bureau des 297 Recherches géologiques et minières.

Greigert, J., \& Pougnet, R. (1967). Essai De Description Des Formations Géologiques De La République Du Niger.

Hallberg, R. O. (1976). A Geochemical Method for Investigation of Palaeoredox Conditions in Sediments. Ambio, 4, 139-147.

He, B., Xu, Y. G., Zhong, Y. T., \& Guan, J. P. (2010). The Guadalupian-Lopingian Boundary Mudstones at Chaotian (SW China) Are Clastic Rocks Rather Than Acidic Tuffs: Implication for a Temporal Coincidence between the End-Guadalupian Mass Extinction and the Emeishan Volcanism. Lithos, 119, 10-19.

https://doi.org/10.1016/j.lithos.2010.06.001

Hofmann, P., Ricken, W., Schwark, L., \& Leythaeuser, D. (2001). Geochemical Signature and Related Climatic-Oceanographic Processes for Early Albian Black Shales: Site 417D, North Atlantic Ocean. Cretaceous Research, 22, 243-257. https://doi.org/10.1006/cres.2001.0253

Karche J. P., \& Vachette M. (1976). Migration des complexes sub-volcaniques à structures annulaires du Niger. Conséquences. Comptes rendus de l'Académie des Sciences, Paris, 282.

Kogbe, C. A. (1981). Cretaceous and Tertiary of the Iullemmeden Basin in Nigeria (West Africa). Cretaceous Research, 2, 129-186. https://doi.org/10.1016/0195-6671(81)90007-0

Mathey, B., Lang, J., Pierre, C., \& Alzouma, K. (1991). Effets combinés de l'eustatisme et des variations climatiques: l'exemple des premières transgressions du crétacé supérieur dans le bassin des Iullemmeden (Niger). Conséquences. Comptes rendus de l'Académie des Sciences Paris, 312, 523-528.

McLennan, S. M., \& Taylor, S. R. (1991). Sedimentary Rocks and Crustal Evolution, Tectonic Setting and Secular Trends. Journal of Geology, 99, 1-21.

https://doi.org/10.1086/629470

McLennan, S. M., Nance, W. B., \& Taylor, S. R. (1980). Rare Earth Element-Thorium Correlation in Sedimentary Rocks and the Composition of the Continental Crust. Geochimica et Cosmochimica Acta, 44, 1833-1839.

https://doi.org/10.1016/0016-7037(80)90232-X 
Meister, C., Alzouma, K., Lang, J., Mathey, B., \& Pascal, A. (1992). Les ammonites du Niger (Afrique Occidentale) et la transgression transaharienne au cours du Cenomanien-Turonien. Géobios, 25, 55-100. https://doi.org/10.1016/S0016-6995(09)90038-9

Moosavirad, S. M., Janardhana, M. R., Sethumadhav, M. S., Moghadam, M. R., \& Shankara, M. (2011). Geochemistry of Lower Jurassic Shales of the Shemshak Formation, Kerman Province, Central Iran: Provenance, Source Weathering and Tectonic Setting. Geochemistry, 71, 279-288. https://doi.org/10.1016/j.chemer.2010.10.001

Moumouni, A., \& Fryar, A. E. (2017). Controls on Groundwater Quality and Dug-Well Asphyxiation Hazard in Dakoro Area of Niger. Groundwater for Sustainable Development, 5, 235-243. https://www.elsevier.com/locate/gsd https://doi.org/10.1016/j.gsd.2017.08.004

Nesbitt, H. W., \& Young, G. M. (1982). Early Proterozoic Climates and Plate Motions Inferred from Major Element Chemistry of Lutites. Nature, 299, 715-717. https://doi.org/10.1038/299715a0

Parrish, J. T., \& Curtis, R. L. (1982). Atmospheric Circulation, Upwelling, and Organic-Rich Rocks in the Mesozoic and Cenozoic Eras. Palaeogeography, Palaeoclimatology, Palaeoecology, 40, 31-66. https://doi.org/10.1016/0031-0182(82)90084-0

Pascal, A., Alzouma, K., Lang, J., Mathey, B., \& Meister, C. (1991). Les transgressions Cénomano-turoniennes dans le basin des Iullemmeden (Niger): Apports de l(analyse des argiles et des elements en traces. Géologie Alpine Mémoire, No. 17, 99.

Peters, K. E., \& Moldowan, J. M. (1993). The Biomarker Guide: Interpreting Molecular Fossils in Petroleum and Ancient Sediments. Englewood Cliffs, NJ: Prentice-Hall, Inc.

Pettijohn, F. J. (1975). Sedimentary Rocks (3rd ed. 628 p.). New York: Harper and Row.

Pi, D. H., Jiang, S. Y., Luo, L., Yang, J. H., \& Ling, H. F. (2014). Depositional Environments for Stratiform Witherite Deposits in the Lower Cambrian Black Shale Sequence of the Yangtze Platform, Southern Qinling Region, SW China: Evidence from Redoxsensitive Trace Element Geochemistry. Palaeogeography, Palaeoclimatology, Palaeoecology, 398, 125-131. https://doi.org/10.1016/j.palaeo.2013.09.029

Rat, P., Lang, J., Alzouma, K., Dikouma, M., Johnson, A., Laurin, B., Mathey, B., \& Pascal, A. (1991). Coastal Marine Basins as Records of Continental Paleoenvironments (Gulf of Guinea and Iullemmeden Cretaceous and Tertiary Basins). Journal of African Earth Sciences (and the Middle East), 12, 23-30. https://doi.org/10.1016/0899-5362(91)90054-3

Roser, B. P., \& Korsch, R. J. (1986). Determination of Tectonic Setting of SandstoneMudstone Suites Using $\mathrm{SiO}_{2}$ Content and $\mathrm{K}_{2} \mathrm{O} / \mathrm{Na}_{2} \mathrm{O}$ Ratio. The Journal of Geology, 94, 635-650. https://doi.org/10.1086/629071

Roser, B. P., \& Korsch, R. J. (1988). Provenance Signatures of Sandstone-Mudstone Suites Determined Using Discriminant Function Analysis of Major-Element Data. Chemical Geology, 67, 119-139. https://doi.org/10.1016/0009-2541(88)90010-1

Rowe, H., Hughes, N., \& Robinson, K. (2012). The Quantification and Application of Handheld Energy-Dispersive X-Ray Fluorescence (ED-XRF) in Mudrock Chemostratigraphy and Geochemistry. Chemical Geology, 324-325, 122-131. https://doi.org/10.1016/j.chemgeo.2011.12.023

Sempéré, T. (1981). Le contexte sédimentaire du gisement d'uranium d'Arlit (République du Niger) (382 p.). Thèse de doctorat, Paris: ENSMP.

Suttner, L. J., \& Dutta, P. K. (1986). Alluvial Sandstones Composition and Paleoclimate, I, Framework Mineralogy. SEPM Journal of Sedimentary Research, 56, 329-345. https://doi.org/10.1306/212F8909-2B24-11D7-8648000102C1865D

Wagani, I. (2007). Potentialité uranifère des sources volcaniques envisageable pour la 
formation des minéralisations de la région d'Arlit (Niger) (283 p.). Thèse de Doctorat de l'Université Paris-Sud.

Wanty, R. B., \& Goldhaber, M. B. (1992). Thermodynamics and Kinetics of Reactions Involving Vanadium in Natural Systems: Accumulation of Vanadium in Sedimentary Rocks. Geochimica et Cosmochimica Acta, 56, 1471-1483.

https://doi.org/10.1016/0016-7037(92)90217-7

Yahaya, M. (1992). Dynamique sédimentaire du Guézouman et des formations viséennes sous-jacentes en liaison avec la tectonique, le volcanisme et le climat, paléomilieux des gîtes uranifères d'Arlit (Niger) (357 p). Thèse Doctorat troisième cycle, Dijon: Université de Dijon.

Zhou, C. M., \& Jiang, S. Y. (2009). Palaeoceanographic Redox Environments for the Lower Cambrian Hetang Formation in South China: Evidence from Pyrite Framboids, Redoxsensitive Trace Elements, and Sponge Biota Occurrence. Palaeogeography, Palaeoclimatology, Palaeoecology, 271, 279-286.

https://doi.org/10.1016/j.palaeo.2008.10.024 